Síntese - Rev. de Filosofia

v. 39 N. 123 (2012): 31-52

\title{
A IDEla de Sistema no PENSAMENTo CLÁssico GREGO (I)
}

(The idea of system in Greek classical thinking)

Marcelo F. de Aquino*

Resumo: Resumo: $\mathrm{O}$ artigo constitui a primeira parte de um estudo sobre a gênese da ideia de sistema no pensamento de Lima Vaz. Esta parte percorre as primeiras trilhas seguidas por esta ideia no pensamento grego, analisando a sua primeira aparição e a sua germinação no pensamento científico grego e na cultura arcaica da polis grega até sua eclosão na obra de Platão.

Palavras-chave: Platão, Vaz, sistema, liberdade, metafísica, ética.

Abstract: This article presents the first part of a research into the origin of the idea of system in the thought of Lima Vaz, and focuses on the beginnings of that idea in Greek thinking. Its first appearance and germination in Greek scientific thinking and in the culture of the archaic Greek polis will be analysed as well as its emergence in Plato's work.

Keywords: Plato, Vaz, system, freedom, metaphysics, ethics.

\footnotetext{
* Doutor em Filosofia pela Pontifícia Universidade Gregoriana e Pós-Doutor em Filosofia pelo Boston College. Professor Titular do Programa de Pós-Graduação em Filosofia e Reitor da Universidade do Vale do Rio dos Sinos - UNISINOS, São Leopoldo, RS, Brasil. Artigo submetido a avaliação no dia 04/01/2012 e aprovado para publicação no dia 01/03/ 2012 .
} 


\section{Introdução}

ideia de sistema ${ }^{1}$ é uma das raízes da civilização que ao longo de
26 séculos coloca a razão demonstrativa no centro do seu universo
simbólico. Esse construto teórico propõe-se pensar a liberdade ou unir dialeticamente liberdade e razão. Nele a liberdade não é exterior à razão. É intrínseca ao movimento de sua autoconstituição, ou, antes, é essa autoconstituição mesma. Seu desafio maior é pensar a liberdade no próprio coração da necessidade racional que preside a construção do sistema das razões universais, e, assim, instaurar uma ordem translúcida às razões individuais numa história enfim sensata. O problema das relações entre Sistema e Liberdade configura uma opção intelectual básica cujas repercussões marcam profunda e decisivamente a história espiritual do ocidente. Se a razão demonstrativa é, por essência, sistemática, e se o sistema postula uma homologia com a realidade, onde situar a liberdade no interior do sistema? Essa é uma questão decisiva que, de Platão a Hegel, impele o desenvolvimento da ideia de sistema na filosofia ocidental.

A trajetória da ideia de sistema na história intelectual do ocidente ajuda a compreender os problemas fundamentais dessa civilização que se vê confrontada com o risco, desconhecido por outras tradições civilizatórias, de explicitar, criticar e permanentemente reorganizar as lógicas que orientam

\footnotetext{
** Este artigo faz parte de meu Projeto de Pesquisa junto ao Programa de Pós-Graduação em Filosofia da UNISINOS. Nele retomo textos publicados pelo Pe. Henrique de Lima Vaz, a saber: Platão Revisitado. Ética e Metafísica nas origens platônicas. Síntese Nova Fase 61 (1993), 181-197 (= PR); Ética e Razão moderna, Síntese Nova Fase 68 (1995), 5385 (= ER); Escritos de Filosofia II - Ética e Cultura. São Paulo, Loyola, 1988 (=EC); Escritos de Filosofia III - Filosofia e Cultura. São Paulo, Loyola, 1997, 3-99 (=FC); Escritos de Filosofia IV - Introdução à Ética Filosófica 1. São Paulo, Loyola, 1999, 85162 (EF1); Escritos de Filosofia V - Introdução à Ética Filosófica 2. São Paulo, Loyola, 2000, 11-22 (EF2); Escritos de Filosofia VII - Raízes da modernidade. São Paulo, Loyola, 2002 (RM). Ética e Direito. São Paulo, Landy e Loyola, 2002 (ED). Usei abundantemente o Relatório de Pesquisa (CNPq - Processo 301665/87 - 7) - A construção hegeliana: um paradigma da racionalidade sistêmica, manuscrito inédito que me foi disponibilizado pelo colega Rubens Godoy Sampaio a quem agradeço o acesso por meio digital do espólio não editado do Pe. Vaz. Tomei conscientemente a decisão de usar as fontes vazianas de maneira heterodoxa, segundo o cânone vigente, pois o excessivo uso do aparato crítico no corpo do artigo quebraria a fluidez da argumentação. Carlos Alberto Gianotti corrigiu o português e Marlise Horn da Silva formatou o texto. Obrigado a ambos.

${ }^{1}$ EF2 12: "O termo sistema é a transliteração do grego sýstema, proveniente do verbo sýnistánai, synistemí, que significa "estar de pé” ou "estou de pé". Da acepção metafórica inicial aplicada a significar "conjunto" ou "reunião", o termo systema foi empregado para designar o discurso (logos) cujas partes se inter-relacionam por meio de conexões lógicas de sorte a formar um todo ordenado segundo critérios de natureza lógica. A definitiva transposição filosófica do termo sýstema deve-se aos estoicos que o aplicaram à totalidade do universo ordenado (kósmos), vindo a designar posteriormente o todo do discurso filosófico em suas três partes: Lógica, Física e Ética.” Ver F. P. Hager e Ch. Strub, System, in Historisches Wörterbuch der Philosophie X (1998), 824-856.
} 
as coordenadas fundamentais desse universo - crenças, costumes, representações, organização social e política - segundo as quais se exerce a ação dos indivíduos e dos grupos. As linhas dessa trajetória apontam para o fenômeno contemporâneo da rápida expansão da racionalidade sistêmica como estrutura simbólica básica da nossa civilização que, aparentemente, se estende implacável a todas as manifestações da cultura contemporânea ${ }^{2}$.

A noção de sistema, hoje em dia, alimenta-se do dinamismo intrínseco do sistema mundial da tecnociência como organismo autorregulado de produção de conhecimentos. Adquiriu uma tecnicidade instrumental e um rigor formal que a tornaram a mais eficaz e poderosa matriz organizacional da vida e das ideias na cultura contemporânea. O Estado e o mercado são sujeitos coletivos que se apresentam como portadores dessa racionalidade absolutamente universal. Tal hegemonia parece não conhecer limites na sua expansão. Provoca, em contrapartida, vagas sucessivas de contracultura e de análises críticas da racionalidade ocidental, que gestam universos simbólicos alternativos que têm como matriz comum a ideologia do individualismo ou a contestação da desrazão levantada pelo niilismo.

Essa trajetória une dois pontos heurísticos distintos, mas estreitamente relacionados, que convergem na célebre identidade dialética entre o racional e o efetivo ${ }^{3}$ proclamada por Hegel como fio condutor do seu sistema. Esses dois pontos constituem as duas vertentes da ideia de sistema: a vertente lógico-formal na qual a construção sistemática procede segundo a norma da demonstratividade, da ordem e da consistência que caracterizam a razão demonstrativa; e a vertente hermenêutica na qual a construção sistemática se apresenta como código interpretativo da inteligibilidade da efetividade que se supõe, justamente, como capaz de ser traduzida na ordem das razões do sistema. A ordem das razões, do ponto de vista lógicoformal, se apresenta, por definição, como sistemática. A ordem da efetividade, do ponto de vista hermenêutico, por suposição, é sistematizável.

Formas da razão sistêmica pulsam na história da filosofia ocidental, ora como lógica do discurso, ora como hermenêutica da efetividade. A suposição fundamental sobre a qual repousa o edifício intelectual de nossa civilização é que a lógica contém em si uma virtualidade hermenêutica, e que a hermenêutica se exerce segundo os cânones da lógica. A trajetória da ideia de sistema se assenta sobre essa correspondência originária entre lógica e hermenêutica.

\footnotetext{
${ }^{2}$ Hoje em dia são correntes as seguintes acepções de sistema: filosófica, crítica, formal, linguística, teoria geral dos sistemas, política, econômica e tecnocientífica.

${ }^{3}$ Ver a distinção hegeliana entre wirklich (efetivo) e Wirklichkeit (efetividade) na Ciência da Lógica, e real (real), Realität (realidade) e Dasein (ser-aí) na anotação do § 6.ำ da Enciclopédia das Ciências Filosóficas.
} 
A origem do procedimento intelectual consagrado na tradição grega como lógos apodeiktikós (discurso demonstrativo) ou lógos epistemonikós (discurso científico) deve ser buscada no postulado da homologia ou correspondência entre ordem do discurso e ordem da efetividade. A tarefa de definir formas e regras do discurso que o tornem apto a exprimir essa homologia apresenta-se necessariamente como complementar ao próprio discurso da ciência. Acompanha os primeiros esboços do pensamento científico. Constitui-se em metadiscurso sob a denominação de logikè epistéme (ciência lógica). A atitude do thaumádzein (admirar-se), da qual Platão ${ }^{4} \mathrm{e}$ Aristóteles ${ }^{5}$ fazem nascer a ciência e a filosofia, está ligada à descoberta ou explicitação das primeiras e mais elementares formas dessa homologia, como, por exemplo, o aparecimento da prosa filosófica em Anaximandro de Mileto. A condução necessária à ideia de sistema pelo exercício da razão demonstrativa é o fio condutor que permite acompanhar o desenvolvimento da razão teórica na história da cultura ocidental. Na ideia de sistema está presente a intenção explicativa que postula a homologia entre ordem das razões e ordem da efetividade. Essa intenção define a finalidade intrínseca do sistema como obra do conhecimento.

Uma característica fundamental da ideia platônico-aristotélica de sistema consiste na ordem sistemática das razões que é, ao mesmo tempo, discurso explicativo da realidade e discurso normativo do agir humano, segundo a homologia pressuposta entre a estrutura da efetividade e a estrutura do sistema, ao qual se agregará a práxis humana em busca de racionalidade e sensatez. Outra característica da ideia platônico-aristotélica de sistema é sua abertura interativa com o mundo circundante. Ao reconhecer por primeiro a pluralidade dos diferentes usos da razão, ou formas distintas de racionalidade, que obedecem a métodos distintos segundo a diferença de seus objetos, Aristóteles distinguiu diversos tipos de saber e, portanto, diversas formas do discurso demonstrativo correspondentes aos diversos usos da razão. Deu o passo decisivo no caminho que conduziu à concepção analógica do discurso sistemático.

\section{Primeiras trilhas temáticas da ideia de sistema}

A ideia de sistema percorre algumas trilhas temáticas nas origens do pensamento científico grego e na crise e transformação da cultura grega arcaica nos séculos VII - V a. C. até alcançar seu pleno desenvolvimento e elaboração na obra de Platão. Eis algumas dessas trilhas. A descoberta da

${ }^{4}$ Teet. $155 \mathrm{~d}$.

${ }^{5}$ Met. I, 2, 982b 11-20. 
demonstração matemática, provavelmente no ambiente do primeiro pitagorismo, bem como os primeiros esboços da ideia de "corpo axiomático", por Xenófanes e Parmênides, tentativas pré-euclidianas de articulação lógica dos stoicheia (elementos) da demonstração matemática. A descoberta da ideia de nómos (lei) no campo da experiência jurídico-política e sua extensão à natureza pela homologia entre pólis e kósmos. Igualmente, a ideia de táxis (ordem) na tradição pitagórica, nos seus aspectos lógicomatemático, físico, ético e religioso ${ }^{6}$. A descoberta do esquema teleológico na physis (natureza), com o postulado do nous (intelecto) ordenador por Anaxágoras, Diógenes de Apolônia e o Sócrates de Xenofonte. A elaboração das formas e regras do discurso retórico na Sofística do século $\mathrm{V}$ a. C. e sua interrelação com o desenvolvimento da prosa filosófica. O avanço da teoria do conhecimento no contexto do relativismo socrático e da teoria do "homem-medida" defendida por Protágoras, e a teoria da pant'alethé. O nascimento da ciência do ethos (Ética) situado no âmbito dos problemas sofístico-socráticos, como solução ao conflito entre physis e nómos (natureza e convenção). A integração do domínio da ação humana no seu aspecto normativo-prático no projeto de reorganização do universo simbólico da sociedade sobre as bases do lógos demonstrativo, projeto assumido historicamente pela Filosofia na qual tem origem, justamente, a ideia de sistema.

Essas trilhas temáticas confluem para a obra e o ensinamento de Platão e de Aristóteles, na idade de ouro da vida intelectual de Atenas na primeira metade do século IV a. C. A partir de então, a ideia de sistema germinará na sua significação arquetipal reconhecida ao longo de toda a cultura ocidental. Estruturará conceitualmente e organizará didaticamente a Filosofia na época helenística, em sentido análogo ao que será o sistema na filosofia moderna ${ }^{7}$.

\section{Para uma leitura renovada de Platão}

A discussão atual sobre os paradigmas historicamente propostos para a interpretação do pensamento platônico é o ponto de partida do presente estudo da ideia de sistema ${ }^{8}$ na leitura vaziana de Platão ${ }^{9}$. A obra escrita de Platão - diálogos da juventude ou socráticos, da maturidade, da velhice ou

\footnotetext{
${ }^{6}$ Górgias, 507e -508a; Rep.

${ }^{7}$ Cabe lembrar que sistema no epicurismo e no estoicismo não apresenta as características axiomático-dedutivas dos sistemas racionalistas da modernidade europeia pósrenascimental inspirados pelas obras de Duns Scotus e de Francisco Suárez.

${ }^{8}$ No Fedro, 264 c3, Platão já exigia do lógos que se constituísse como ôsper zôon synistánai (organismo vivo).

${ }^{9}$ PLATON. Oeuvres Complètes. Paris: Société d'Édition "Les Belles Lettres", 1949. IDEM, Werke in acht Bänden grieschich und deutsch. Herausgegeben von Günther Eigler. Darmstadt: Wissenschaftliche Buchgesellschaft, 2001. Ver REALE, G. Para uma nova interpretação de Platão. São Paulo: Loyola, 1997.
} 
metafísicos e o Timeu - foi a única dentre as dos filósofos antigos a chegar até nós, praticamente, na sua totalidade. Juntamente com os textos dos diálogos, a Antiguidade conheceu também uma tradição indireta das doutrinas expostas oralmente por Platão na Academia e que ficaram conhecidas como ágrapha dógmata (doutrinas não escritas), que remontariam à fundação da Academia, ou seja, à época dos diálogos da maturidade. Seu eixo central é a chamada Protologia (Teoria dos Princípios), fragmentariamente transmitida nos ágrapha dógmata. A Protologia, que os Testimonia platonica ${ }^{10}$ atribuem aos ágrapha dógmata, diz respeito às mais altas questões da especulação platônica e ao fecho da abóboda reclamado pela construção intelectual cujas linhas podem ser traçadas a partir dos diálogos. A ela se deve recorrer, não obstante o interdito de Schleiermacher, no intento de compreender a ideia de sistema subjacente à Metafísica platônica.

Os Testimonia platonica possibilitaram que traços quase fugidios dessa tradição indireta do pensamento platônico chegassem até nós, mas numa figura que parece não apresentar clara relação com a que Platão traçou nos diálogos. O caráter fragmentário dessa tradição indireta das doutrinas não escritas fez com que a relação entre a filosofia dos diálogos e as doutrinas não escritas tenha se constituído num enigma da antiga Academia. A historiografia moderna privilegia de maneira quase absoluta o texto dos diálogos como fonte para a interpretação de Platão. Faz das doutrinas não escritas um curioso produto senil do pensamento de Platão no seu declínio, ou as considera obra de seus discípulos, ou ainda as atribui à óptica deformada com que Aristóteles leu os Diálogos ou ouviu as lições do Mestre.

O paradigma hermenêutico da Escola de Tübingen-Milão relaciona a exegese dos diálogos da juventude e a própria relação entre os diálogos da juventude e os da maturidade às doutrinas não escritas. Analisa e integra o conteúdo das doutrinas escritas ao esquema interpretativo mais amplo da Protologia. O termo para o qual os diálogos apontam deve ser estabelecido em sua relação com as doutrinas não escritas. Em resumo, afirma que Platão, desde o inicio de sua atividade literária, pressupunha o ensinamento oral como fundamento e complemento das doutrinas escritas. Os diálogos da juventude, segundo critérios hermenêuticos traçados a partir das doutrinas não escritas, manifestam finalidade protréptica, educativa e moral.

As linhas germinais da ideia de sistema em Platão delineiam-se sobre o fundo da Protologia das doutrinas não escritas que inspira uma intrépida confiança no poder arquitetônico da razão. Os ágrapha dógmata movemse com o propósito audaz de se alcançar o Primeiro princípio de toda a realidade, de onde contemplam sinoticamente todo o imenso país das ideias

\footnotetext{
10 Testimonia platonica, publicados por K. GAISER em Apêndice ao seu livro Platons ungeschriebene Lehre: Studien zur systematischen und geschichtlichen Begründung der Wissenschaften in der platonischen Schule. Stuttgart, Klett Verlag, 1963, 443-557.
} 
e dele retornam para prender a multiplicidade dos seres nos laços do mais belo dos vínculos, ou seja, da razão proporcional, ou analogia. A ideia de sistema, à luz dos ágrapha dógmata, compreende essa força arquitetônica da razão e a visão sinótica do todo. Apresenta uma estrutura convergente a modo de um triângulo isósceles em que os lados iguais representam as vertentes lógico-matemática e lógico-ética do sistema e em cujo vértice formado por estes lados está o Princípio supremo do Uno-Bem. É coroada pela dialética do Bem-Uno. É um corpo explicativo de razões da theoría e um corpo normativo da práxis. É uma Henologia, ou Metafísica do Uno, e uma Ética metafísica.

\section{Reconstrução da Teoria dos principios}

A crítica sofística à estrutura ético-religiosa que servia de fundamento à cultura grega e a consequente tentativa por parte do indivíduo de reordenar as grandes linhas dessa estrutura, e assim superar a crise provocada pela ruptura do ethos tradicional, é o pano de fundo do imenso esforço empreendido por Platão de transpor, nos tempos pós-socráticos, o problema da liberdade individual para o plano metafísico. A Teoria dos princípios torna possível a visão abrangente da realidade, constituindo o vértice da Metafísica platônica. Sua reconstrução adquire fundamental importância para o estudo do problema da liberdade nos tempos pós-socráticos.

O pressuposto socrático da estrita homologia entre epistéme e areté fundamenta o cognitivismo ético do pensamento clássico grego que submete a práxis virtuosa à norma da razão. Aos olhos de Platão, ele implica necessariamente uma correlação estrutural entre razão e liberdade. Em termos sistêmicos, o pressuposto socrático, na medida em que a justificação racional da práxis caminha para buscar seus fundamentos nos princípios supremos aos quais a razão deve elevar-se, implica relação estrutural da Ética à Metafísica.

Para Platão, portanto, a Metafísica é o horizonte da Ética. A Ética é o avançar ao encontro desse horizonte traçado pela Ontologia do Bem-Uno. A Ética se encaminha para colocar a práxis inteiramente sob regência da theoría. Isso significa suprassumir a necessidade ética do destino na necessidade manifestada da razão. Ao descortinar o espaço da Metafísica, Platão igualmente descobre as dimensões conceptuais segundo as quais pode pensar a liberdade na sua essência mais genuína, tornando possível a construção da Ética como ciência da liberdade.

A experiência da liberdade como autárkeia, autodeterminação, segundo a lógica imanente e a necessidade inteligível que regem o movimento da ideia ou do conceito, ou seja, que se mostra totalmente transparente a si 
mesma na ordem das suas razões, passa a ser decisiva na formação do conceito ocidental de liberdade. A autárkeia é eu práttein, plenitude do bem agir ${ }^{11}$. Está ligada às origens políticas da ideia grega de liberdade e constitui a dimensão fundamental que orientará todo o desenvolvimento posterior da reflexão filosófica sobre a liberdade na sua face ética. Sobre ela se assentam três outras dimensões que tornam possível a construção da Ética como ciência da liberdade: a liberdade de arbítrio, a liberdade de escolha e a liberdade de autonomia. A dialética da liberdade como arbítrio foi o caminho seguido pela Sofística e pelos Cínicos; como escolha, foi o caminho socrático; como autonomia apresenta traços diferentes, caso enverede ou pelo arbítrio ou pela escolha.

O caminho socrático de submissão da livre decisão à deliberação antecedente inaugura o cognitivismo ético grego. Platão ${ }^{12}$ e Aristóteles ${ }^{13}$ são seus seguidores mais ilustres. Essa primazia da liberdade de escolha insere o movimento da liberdade no dinamismo do lógos. Orienta-o segundo a direção da Metafísica platônica do bem, ou segundo a direção da Ciência aristotélica da práxis. Essa última também coroada pela theoría como forma suprema da eudaimonía. O desenho da figura da liberdade, que preside ao desenvolvimento da Ética clássica pela liberdade de autonomia, a qual eleva a liberdade de escolha a repousar na identidade do Verdadeiro e do Bem, encontra sua realização paradigmática na figura do sábio e o télos do seu movimento para o Bem na vida contemplativa.

Platão foi o primeiro na história espiritual do ocidente a se lançar no extraordinário périplo da Odisseia de tentar elevar a hermenêutica da liberdade humana compreendida como práxis humana na sua prerrogativa de livre agir ao plano de uma Metafísica da liberdade, ou de uma Ética enraizada na necessidade suprema do ser. Essa aventura o lançará nas rotas do deúteros plous ${ }^{14}$ (segunda navegação) através do oceano ${ }^{15}$ do lógos do qual tornará para estabelecer a natureza, a cidade e o indivíduo nos firmes vínculos do inteligível. O destino da ciência dos fins, ou Ética, está intrinsecamente ligado ao da ciência dos princípios, ou Metafísica. A Odisseia platônica instaura um arquétipo sistêmico que pela referência à normatividade da ideia, isto é, ao fundamento metafísico do ser, regula a crítica aos mitos cosmogônicos das origens e a crítica aos mitos utópicos dos fins. Abre o espaço para a constituição da Ética e da Política como ciências da regulação racional da práxis humana no mundo e no tempo da história.

\footnotetext{
${ }^{11}$ Mais tarde, Plotino ensinará em Enéadas, VI, 8 que a suprema fruição do Uno em si mesmo é o paradigma ideal da autárkeia.

${ }^{12}$ Ver a escolha da vida no mito de Er em Rep. X, 614b - 621d.

${ }^{13}$ Ver a análise da liberdade de escolha em Et. Nic., III, 4-5.

${ }^{14}$ Cfr. Fed., 99d.

${ }^{15}$ A metáfora de pélagos com relação às ideias e ao lógos aparece em Banq. 210d, contudo contemplado e não navegado.
} 
O lógos demonstrativo ou a epistéme em sentido propriamente platônico, segundo o qual a ciência deve necessariamente elevar-se à Teoria dos princípios, vértice da Metafísica, é o novo cimento com que Platão tentará firmar as bases da cultura grega nos tempos pós-socráticos. A força estruturadora e aglutinadora da epistéme platônica parte da Teoria dos princípios. A areté, ideal grego da excelência da vida, é o alicerce a ser firmemente assentado pelo lógos epistêmico como fundamento da realidade. Este tema está onipresente nos diálogos da juventude ${ }^{16}$. Ele pode ser considerado o eixo central, em torno do qual se organizam as grandes linhas da Metafísica platônica. Estrutura as dimensões conceptuais que permitem pensar a liberdade, tornando possível a construção da Ética como ciência da liberdade. A Metafísica platônica converge para o vértice conceptual da Ciência dos princípios. Por sua vez, a Ética platônica está inexoravelmente ligada à Metafísica. A Ciência dos fins está intrinsecamente ligada à Ciência dos princípios.

Lógos (verdade do ser) e areté (excelência da vida), ou theoría e práxis, ou ainda livre necessidade da razão e razão necessária da liberdade, em sua convergência na unidade do Uno-Bem, constituem a estrutura fundamental da primeira grande construção sistêmica da filosofia ocidental, fundamentalmente metafísico-ética.

A transposição platônica do problema da liberdade individual para o plano metafísico torna-se possível graças à construção do caminho em que o universo simbólico das crenças, dos costumes e das representações alcança a theoría do ser. Nesse ponto remoto para o qual convergem todas as linhas do espaço metafísico-ético tem lugar a negação dialética do mito do destino. Nele torna-se possível o desenrolar-se da ordem das razões cuja cadeia se eleva até o cimo mais alto tanto da Metafísica como da Ética. É o lugar do definitivo encontro da razão da liberdade. Os primeiros passos da dialética ascendente platônica, o fio que une a ordem das razões em direção ao vértice onde lógos e areté, ou theoría e práxis convergem na unidade do Uno-Bem, percorrem a trilha aberta pelo questionamento socrático sobre a areté para elevar-se em seguida, pelos degraus sucessivos das ideias, até o Princípio anipotético do todo.

Platão constrói a primeira Metafísica da liberdade sobre o solo históricocultural $^{17}$ do ideal grego da areté. A experiência da autárkeia, domínio de si mesmo, e da irradiante plenitude do kaloskagathós, o belo e bom que

\footnotetext{
${ }^{16}$ Esta datação da seriação cronológica dos diálogos platônicos não implica um esquema evolutivo estrito, nem faz do tema da areté a marca dos primeiros passos da reflexão platônica, deixados para trás a partir da sua maturidade.

${ }^{17}$ Este solo apresenta-se, nos tempos socrático-platônicos, sulcado em muitos sentidos e revolvido pela passagem da ilustração sofística e pelas grandes transformações sociais e políticas que a Atenas do século $\mathrm{V}$ conheceu.
} 
acompanha o agir daquele ao qual se atribui a excelência da areté, formam o núcleo constitutivo do ideal da areté. Ora, no contexto da crise do ethos tradicional, quando se obscureceram as razões oferecidas pela paideia tradicional, e se a ação que procede da areté participa da sua eu práttein (excelência), Platão pergunta-se onde buscar a razão desta excelência? Ou ainda, como dar um fundamento razoável à afirmação que o virtuoso é verdadeiramente autárkes, é livre? Ele não dirige essa interrogação ao indivíduo na frágil e efêmera condição da sua mortalidade. Dirige-a ao lógos que habita no indivíduo empírico, mas que ao se manifestar o eleva acima da sua condição mortal e revela a sua verdadeira natureza, descerrandolhe o horizonte da contemplação do Ser e do Bem.

A realidade histórico-cultural do ethos grego organizado em torno do ideal da excelência humana ou areté é o ponto de partida do caminho seguido pela Metafísica platônica. O caminho metafísico que parte da areté conduz à plenitude do Ser como perfeição ou do Bem (agathón). Ao longo dele interroga-se o lógos, o que traz consigo a disposição de deixar-se guiar por ele. $\mathrm{O}$ caminho que se abre aos interrogantes é o caminho dialógico. Seguindo-o, os interrogantes tornam-se itinerantes de um méthodos que os conduzirá à visão das ideias e dos princípios do ser. O itinerário da Metafísica platônica parte da experiência da vida moral como manifestação da areté ou virtude, o bem humano por excelência, para conduzir em direção da transcendência da Ideia como Ser.

A ascensão metafísica em direção à epistéme propriamente dita, que é a Ciência das ideias, desenrola-se no espaço do lógos descoberto a partir da experiência do Ser como "perfeição" ou areté. Pode ser empreendida, já nos diálogos socráticos, pela vertente lógico-física que conduz ao eidos das realidades naturais, e pela vertente lógico-ética que conduz ao eidos das virtudes. Ambas elevam-se à ideia como eidos-areté e convergem para a suprema unidade do agathón-én (Bem-Uno).

Graças aos desdobramentos conceptuais da complexa noção de areté, a Metafísica dos princípios pode ser dita uma Metafísica da liberdade. Por sua vez, a iluminação da face da Metafísica dos princípios voltada para o itinerário humano da liberdade pela luz inteligível do Bem ${ }^{18}$ constitui a Ética, Ciência do ethos ou Ciência da areté. Desta sorte, a Metafísica, Ciência dos princípios, mostra-se como normativa para o caminho da liberdade. Essa normatividade, constituindo-se como fundamento último da Ética, irá finalmente desvendar o sentido mais profundo da doutrina socrática da virtude-ciência. Oferece igualmente uma indicação hermenêutica segundo a qual o pensamento platônico pode ser interpretado como uma Metafísica da liberdade, uma Ética metafísica que se propõe estabelecer a ciência do ser como norma suprema do agir livre.

${ }^{18}$ Rep. VI, 508e -509 a. 


\section{Primeira trilha temática da ideia platônica de sistema: a vida segundo o lógos, ou o conhecimento do ser como norma do agir}

Platão não expôs em toda a sua coerência a ideia de sistema. As trilhas da sua exposição são várias. Uma primeira parte da reconstrução da Teoria dos princípios que propicia a luz necessária à análise do conteúdo dos ágrapha dógmata. A partir dessa é possível falar de dois níveis de leitura dos diálogos de juventude. Em cada um dos níveis desenha-se a possível relação entre os diálogos de juventude e os da maturidade. Num nível aporético, a leitura se faz de acordo com a chave lógica que mostra o movimento dialético do diálogo desembocando na aporia final e separando Sócrates e seus interlocutores sem que tenham chegado a um consenso satisfatório. Num nível propedêutico, a leitura se faz de acordo com a chave metafísica que permite descobrir nas peripécias terminológicas dos primeiros diálogos os indícios e os prenúncios de um saber superior e como que o presságio ainda obscuro do que será a plena revelação do mundo ideal. É o caso do uso já provavelmente técnico do termo eidos ${ }^{19}$.

A relação aporética entre os diálogos de juventude e os da maturidade se estabelece pela possibilidade da solução lógica da aporia, com a introdução do terceiro termo, a ideia como noetón, ou plenitude de inteligibilidade. A relação propedêutica entre eles se estabelece segundo uma ordem propedêutica na medida em que nos diálogos de juventude cumprem-se todas as preparações lógicas, temáticas e pedagógicas que permitirão mais tarde a subida para o inteligível e o descortinar-se da vasta planície da verdade ${ }^{20}$.

Os diálogos da juventude manifestam finalidade protréptica, educativa e moral. A perspectiva da busca da fundamentação ideal da areté conduz a análise de cada um deles em que duas linhas hermenêuticas se entrecruzam. A linha descendente parte da hipótese da presença normativa da ideia e delineia de modo cada vez mais nítido os contornos de um mundo de valores orientado para a transcendência do $\mathrm{Bem}^{21}$. Como hipótese mais provável, supõe-se que desde o início da atividade literária de Platão a Teoria das ideias já estivesse presente, ao menos nos seus traços fundamentais, e, talvez, já começasse a ser explicitada e desenvolvida no ensinamento oral. A linha ascendente parte da descoberta da alma na sua situação dialógica e colocada sob o signo da obediência socrática ao precei-

\footnotetext{
${ }^{19}$ Ver Eutífron, Hipias Maior, Mênon.

${ }^{20} \mathrm{O}$ mito do Fedro aponta para a contemplação da verdade, para a qual se dirigem todos os trabalhos e penas da alma e onde ela reconhece a sua terra natal e, portanto, recebe a revelação de sua verdadeira natureza.

${ }^{21}$ Ver Rep., VI-VII.
} 
to délfico, linha que se desenrola até alcançar a essência da mesma alma, definida pela sua suggéneia (parentesco) com o inteligível e o divino ${ }^{22}$.

Essa linha hermenêutica ascendente orienta a ordem de leitura dos diálogos de Platão na Antiguidade, sobretudo nos meios neoplatônicos dos séculos V e VI d. C. O roteiro temático dos diálogos da juventude, analisados na perspectiva das exigências lógicas e das implicações éticas da areté, aponta para os fundamentos ou para os princípios da Metafísica da liberdade. Seu prólogo é o Primeiro Alcebíades, que se apresenta como princípio da leitura e da formação filosófica que ensina o conhecimento de si mesmo, sem o qual não se podem conhecer os outros seres. Seu primeiro ato é o Protágoras em cuja cenografia Sócrates prossegue na discussão com seus interlocutores, colocando-lhes a pergunta: "A virtude pode ser ensinada?". Ora, ensinar a virtude não é senão educar para a liberdade. A evidência dessa relação de consequência entre virtude e liberdade supõe, no entanto, que a virtude seja entendida como areté ${ }^{23}$, perfeição ou plenitude do ser e do agir (eu práttein) ${ }^{24}$. A liberdade é, pois, homóloga à epistéme que é a forma da virtude, constituindo seu lógos, ou a definição do seu eidos.

Todas as estações do caminho, ou inquirição, na busca da areté verdadeira sofrem influência das exigências da epistéme. Nos diálogos da juventude, os traços do alvo da inquirição delineiam-se de maneira ainda incerta. Mas sua direção já está perfeitamente definida no momento em que a questão decisiva, ti esti, abre o espaço temático dentro do qual se desenrolará cada um dos diálogos. As exigências da epistéme vão se impondo de maneira sempre mais nítida, até se tornarem claras e explícitas nos diálogos da maturidade. O noetón (inteligível puro) torna-se, cada vez mais, o alvo verdadeiro da inquirição da areté até alcançar a convergência do dialektiké méthodos (caminho dialético) para a unidade da Ideia do bem como alvo, objeto do mégisthon máthema (ciência suprema).

A liberdade, como liberdade verdadeira, será então como selo ou sinete do Bem na alma, que só se tornará visível e seu relevo irá configurar o próprio relevo da alma quando esta for capaz, por sua vez, de marcar com o sinete do ser os objetos do seu conhecimento verdadeiro ${ }^{25}$. No momento em que a alma, tendo chegado ao fim do aprendizado da virtude, torna-se capaz

\footnotetext{
${ }^{22}$ Ver Fed., 79b-d; Rep., X, 611e; Pol., 309c.

${ }^{23}$ Cabe relembrar que a areté é expressão, em cada ser, da táxis (ordem) do kósmos. No homem, lógon echôn, a areté é a face verdadeira da liberdade, ou seja, conformidade com o que é ordenado e divino (Fed., 114e; Rep., 500d-d).

${ }^{24}$ Nesse sentido, ao criticar o mecanismo psicológico compensador no discurso de Zaratustra Von den Lehrstühlen der Tugend, Nietzsche apresenta uma versão desfigurada da areté. Ver NIETZSCHE, F., Nietzsche Werke. Kritische Ausgabe. Herausgegeben von Giorgio Colli u. Mazzino Montinari. Sechste Abteilung, erster Band, Also sprach Zarathustra. Ein Buch für Alle und Keinen (1883-1885). Walter de Gruyter, Berlin: 1968, 28-30.

${ }^{25}$ Fed., 75d.
} 
desse gesto propriamente ontológico com o qual Platão exprime metaforicamente o sentido da nóesis ou da intuição do inteligível puro ${ }^{26}$, revela finalmente sua liberdade essencial: a liberdade para o Bem, em cujo conhecimento alcança a plenitude da sua areté, a certeza da sua imortalidade ${ }^{27}$ e a vitória sobre o destino ${ }^{28}$. Imortalidade da alma e vitória sobre o destino são, pois, elementos essenciais da Metafísica da liberdade segundo Platão.

O caráter aporético dos primeiros diálogos, a partir de um olhar para os Princípios da Metafísica da liberdade, traduz o recurso pedagógico ou, mais exatamente, psicagógico de Platão, na medida em que o amor do saber (philosophia) da alma pouco a pouco se fortalece estimulado pelas interrogações que se levantam ao longo do caminho, até se sentir capaz de empreender a ascensão cuja descrição caberá aos diálogos da maturidade. A consideração de um itinerário psicagógico nos diálogos de juventude, aos quais também pode ser atribuída a condição de lógoi protreptikói (exortações) à Filosofia deve ser entendida de um ponto de vista de metodologia do ensinamento platônico, e não supõe nenhum esquema evolutivo na interpretação do pensamento de Platão ${ }^{29}$.

Na perspectiva desse itinerário psicagógico, o diálogo Mênon, tido como o último dos diálogos da juventude, é uma estação decisiva do caminho seguido por Platão ao longo da sua inquirição. A presença soturna de Anitos, o futuro acusador de Sócrates, hospedeiro do nobre tessálio Mênon e sempre nas vizinhanças dos dois interlocutores do diálogo, permite incluir o Mênon entre os diálogos do ciclo da morte de Sócrates ${ }^{30}$. Estes diálogos, ao mesmo tempo em que desenham os traços da figura ideal de Sócrates e apontam nele o paradigma da nova forma de vida - a vida filosófica - assumem nitidamente tom programático. Podem ser lidos como manifesto de fundação da escola de Platão em que, justamente, filosofar será viver, a exemplo de Sócrates, essa nova vida à luz e sob a regência do lógos. Os diálogos do ciclo da morte de Sócrates consignam a intrepidez dialética com que Platão, ao configurar a vida filosófica a ser vivida na Academia, se lança no seguimento do lógos, indo até o fim da segunda navegação anunciada no Fédon para alcançar as últimas províncias do lógos no país dos Primeiros Princípios, terra natal da Metafísica.

O Mênon, segundo a maioria dos intérpretes, é um diálogo programático em que Platão esboça, sutil e nitidamente, as linhas mestras do ensinamento

\footnotetext{
${ }^{26}$ Rep., VI, 510d-e.

${ }^{27}$ Fed., 105b-107.-; Rep., X, 608c-612a.

${ }^{28}$ Gorg., 523a-527e.; Fed., 107d-115a; Rep., X, 613e-621b.

${ }^{29}$ A esse respeito, ver GADAMER, H.-G., Gesammelte Werke. Bd. 6, Griechische Philosophie II, Platos ungeschriebene Dialektik. J.C.B. Mohr, Tübingen: 1985, 129-153.

${ }^{30}$ Os outros são Apologia, Eutífron, Górgias, Críton e, finalmente, Fédon. A redação deste grupo de diálogos situa-se em torno dos anos que viram a fundação da Academia, ou seja, pouco antes e pouco depois de 387 , ano da primeira viagem de Platão a Siracusa.
} 
que a nascente Academia se propunha administrar aos jovens gregos. A figura exemplar de Sócrates e sua arte de dialogar; o caráter propedêutico do raciocínio matemático no episódio da discussão entre Sócrates e o jovem escravo de Mênon; e o problema da areté - que, estendendo-se em perspectivas sempre mais vastas, abrange as questões do fundamento ontológico do conhecimento, da natureza da alma e de sua imortalidade e da Teoria dos Princípios - são as três dimensões do espaço temático do ensinamento administrado na Academia.

A analogia entre a estrutura do diálogo e o caminho das sombras à claridade que será traçado na alegoria da Caverna manifesta a intenção pedagógica do Mênon. Se submetermos o Mênon ao esquema ascensão-descida que rege a alegoria da Caverna, podemos considerar a primeira parte do diálogo, que culmina com a exposição da doutrina da anámnesis, como o itinerário da ascensão para a verdade; e a segunda parte, aplicação do método matemático da hipótese à busca da definição da virtude, que termina com o insucesso da tentativa de Sócrates para elevar Mênon ao plano das idéias, devendo ambos contentar-se com permanecer no nível da alethés doxa (opinião verdadeira) como o retorno às sombras da Caverna - ou seja, à vida política de Atenas - em cujo fundo desenha-se o perfil sinistro de Anitos.

Nos diálogos programáticos que anunciam a fundação da Academia, um núcleo linguístico metafórico designa o roteiro do saber que a posteridade nomeará Metafísica. Traduz na linguagem da analogia os gestos fundamentais do nosso espírito segundo o ensinamento platônico. As metáforas da ascensão, no Mênon, no Banquete e na República, da navegação, no Fédon, e da visão se enumeram entre as mais ilustres de todo o rico tesouro metafórico da filosofia ocidental. O uso das metáforas da ascensão e da navegação sugere que o roteiro do lógos, para aquele que se decidiu pelo "belo risco" de segui-lo, é assinalado a cada passo por novos apelos e novas exigências, até que o viajante audaz descanse na nóesis (visão) do fim, que é o Uno-Bem e, igualmente, o Belo. Ascensão e navegação traduzem metaforicamente dois postulados metafísicos: a radical insuficiência do aístheton para satisfazer a todas as exigências de explicação do noetón, e a indiscutível prioridade ontológica do noetón sobre o aístheton, como fonte de explicação ${ }^{31}$. O uso das metáforas ascensão, navegação e visão na descrição de um itinerário que deve necessariamente chegar ao fim, oferece a clara exigência do regresso ao começo, fechando o círculo dialético do conhecimento teórico, ou da estrutura fundante da Metafísica. Esse périplo da inteligência, o mais longo e o mais audaz, não é para Platão apenas um exercício intelectual. É uma aventura de vida. É a exigência essencial do filosofar como óntina trópon chré zen (estilo e regra de viver) ${ }^{32}$.

${ }^{31} \mathrm{RM} 225-226$.

${ }^{32}$ Rep., I, 352d. 
O Fédon, mesmo que sob a regência do dualismo órfico-pitagórico somapsyche, inaugura as grandes obras da maturidade de Platão. Faz parte do grupo de diálogos programáticos que anunciam a fundação da Academia ${ }^{33}$ e falam da vida filosófica que nela se tentará viver. Sua interpretação segue dois modelos. O antigo, que vê no diálogo um paramythetikós lógos (discurso de consolação) ou protreptikós lógos (discurso de exortação), e o moderno que nele vê a primeira grande formulação de uma teoria do conhecimento pela literatura filosófica. O Fédon, de fato, é as duas coisas. Pode-se considerá-lo um manifesto programático em que Platão expõe amplamente, pela primeira vez, a Teoria das ideias e sua abertura à Teoria dos princípios. Nele Metafísica e Ética tornam-se possíveis, assim que o conhecimento do ser como norma do agir é aquela raiz da ideia de sistema em que os problemas da práxis são elevados ao plano da theoría. Especificamente, no caso platônico, esta solução é remontada à esfera da Teoria dos princípios.

Certa coerência na complexidade de temas ${ }^{34}$ relativos à ideia de homem que se protrai até ao Timeu desenha-se a partir do Fédon. O tema da relação do homem com tò theion (o divino) sobrepõe-se aos demais temas, tornando-se motivo fundamental que, do Fédon às Leis, percorre a Antropologia platônica. Um paradoxo percorre suas páginas: a meditação sobre a morte como exercício do bem morrer por parte de Sócrates é, igualmente, uma meditação metafísica e é, mesmo, o discurso inaugural da Metafísica no ocidente como discurso reflexivo e autofundante que avança pelo oceano do lógos seguindo o roteiro da segunda navegação. Ora, Sócrates é o modelo ideal dessa vida e sua morte o ato supremo do seu exercício de filosofar. Se esse ato supremo é, ao mesmo tempo, uma meditação metafísica na qual se lançam os fundamentos da Teoria das ideias e se formulam as exigências da Teoria dos princípios, e um caminhar sereno para a imortalidade, é porque, para Platão, o conhecimento do ser é a norma suprema da vida filosófica. Na sua homologia com o Ser, a vida filosófica não pode ser levada pelo fluxo que arrasta a efêmera existência dos mortais. A ela cabe o predicado theia (divina) e, por conseguinte, a imortalidade, predicado das ideias divinas. Essa é a demonstração com a qual Sócrates sela o termo da sua existência mortal e Platão oferece ao filósofo a única forma de imortalidade que a razão, deixada a si mesma, é capaz de entrever: a migração para o país das ideias.

\footnotetext{
${ }^{33}$ A Academia foi fundada em 388 a. C. Muito provavelmente a composição do Fédon situa-se em torno de 385 a. C.

${ }^{34} \mathrm{O}$ tema do lógos verdadeiro, da imortalidade e do destino nos diálogos do ciclo da morte de Sócrates; o tema da educação do indivíduo para a justiça em si mesmo e na cidade, na República; o tema do desejo amoroso ou Eros e do movimento imanente à alma no Banquete e no Fedro; o tema do homem na ordem do universo no Timeu e no livro X das Leis.
} 


\section{Segunda trilha temática da ideia platônica de sistema: a conciliação entre liberdade como essencial à areté e necessidade como predicado do lógos}

Esta segunda trilha parte do pressuposto socrático da unidade da areté e do lógos e sua implicação na conciliação entre liberdade e necessidade - a liberdade como essencial à virtude e a necessidade como predicado da razão. A ideia de táxis (ordem) é a ideia diretriz da exposição platônica que articula e rege a realidade total, i.é, o domínio do Ser verdadeiramente tal, que Platão denomina ontos on, e a solidariedade entre Bem e Ser. Nela se entrecruzam significação metafísica e significação ética. Ela permite, sob a égide da Teoria das ideias, a unificação da Ética, da Política e da Cosmologia, assegurando a justa medida da areté ao indivíduo e à cidade e guiando o Demiurgo na construção do kósmos harmonioso. Exprime estruturalmente uma proporção ou analogia, que une elementos e seres diversos no desmon kallistos... analogia (mais belo dos laços) ${ }^{35}$. Graças a ela, Platão estabelece relação analógica entre as partes da alma e suas virtudes, entre a alma e a cidade, entre a alma e o mundo.

A discussão sobre a dikaiosyne (justiça) na República é o primeiro passo a ser dado nesta trilha. Ao buscar a definição verdadeira da justiça, Platão amplia a discussão com Polemarco, Trasímaco ${ }^{36}$ e Glauco $^{37}$ de sorte a desenhar visão grandiosa da ordem na cidade e no indivíduo unidas pelos laços da analogia ${ }^{38}$, para nelas descobrir o lugar e a definição da justiça política e da justiça na alma. Obedece à lógica profunda que orienta o desenvolvimento do verdadeiro tema posto em discussão por Glauco e Adimanto: como conciliar a prática da justiça com a felicidade e nelas fazer consistir o verdadeiro bem $?^{39} \mathrm{Ou}$ ainda, como conciliar a vida política com a vida virtuosa?

O encadeamento da argumentação que guia o discurso platônico começa por afirmar que o conhecimento da ordem implica o conhecimento do Bem, do qual aquele deriva, e o conhecimento das realidades a serem ordenadas: realidades estruturalmente complexas nas quais o bem deverá residir justamente na unidade ordenada das partes e o mal na multiplicidade desordenada. A ordem assegura a unidade das partes na constituição do todo. Consiste em tà eautou prãttein (cumprir cada uma das partes o que lhe é próprio), de sorte que no todo assim ordenado possa transluzir a presença do Bem.

${ }^{35}$ Timeu, 31c 2-4. Ver Leis, IV, 715e.

${ }^{36}$ Rep. I

${ }^{37}$ Rep. II

${ }^{38}$ Rep. IV, 434d $2-445 \mathrm{e} 4$.

${ }^{39}$ Rep. II, 358e 3 - 360d 8. 
A argumentação avança afirmando que o lugar antropológico da justiça é a práxis individual e social. A justiça está necessariamente presente na práxis que procede da ordem reinante no indivíduo e na cidade. No todo individual e social devidamente ordenado resplandece sua excelência ou areté, em uma palavra, seu bem, estruturado segundo a ordem das partes e obedecendo, portanto, à regência da justiça, areté ordenadora por definição. Três tarefas teóricas centradas na práxis virtuosa se apresentam a Platão para a execução deste desenho, prolongando-se do livro II ao livro VII da República. A primeira (Filosofia Política) é a de descrever uma pólis que seja a imagem da pólis ideal, constituída segundo as exigências do lógos, na qual a ordem possa reinar e a areté política florescer ${ }^{40}$. A segunda (Antropologia), conduzida a partir da primeira segundo o princípio da analogia ${ }^{41}$ é a de mostrar como a ordem da cidade justa se reflete na estrutura da alma individual, de sorte que a areté do indivíduo, cidadão da cidade justa, tenha igualmente a virtude da justiça como norma ordenadora $^{42}$. Estas duas tarefas mostram a necessária relação entre Antropologia e Ética, na República, permeando a divisão platônica das virtudes cardeais. A terceira desdobra-se na inquirição da Ideia do Bem ${ }^{43}$ (Ontologia), fundamento último da justiça, e na descrição do caminho do conhecimento $^{44}$ (Gnosiologia) que leva à Ideia do Bem.

O cumprimento dessas três tarefas teóricas centradas na práxis segundo o bem constitui a viga mestra doutrinal da República e o traçado da trilha temática ora seguida em que se entrelaçam a Antropologia da práxis individual e política, a teleologia da práxis como Ontologia do Bem e a Epistemologia da ciência do Bem. Ora, se a práxis virtuosa, ou segundo o Bem, é por excelência práxis livre, a ideia de sistema que sobre ela repousa seu fundamento segundo o lógos e sua estrutura, será germinalmente a de um sistema aberto.

A noção de modelo e a ordem lógica do discurso são dois registros conceptuais operados aqui por Platão. O modelo concretiza determinado momento do lógico. A lógica da ordem na cidade pede o modelo do Guardião, e a necessidade de conhecer o fundamento último da ordem e, portanto, da justiça, pede o modelo do Filósofo. A noção de modelo, independentemente das figuras do Guardião e do Filósofo, insere-se com coerência na estrutura fundamental da razão platônica segundo a qual tà oratá (coisas visíveis) e tà aisthetá (coisas sensíveis) subsistem por sua participação no modelo das noetá (realidades inteligíveis). No que diz respeito à

\footnotetext{
${ }^{40}$ Rep. II a IV.

${ }^{41}$ Rep. II, 368e $2-369$ b 4.

${ }^{42}$ Rep. IV a VI

${ }^{43}$ Rep. VI.

${ }^{44}$ Rep. VI a VII.
} 
lógica do discurso, a descrição do modelo — sendo ele a concretização de um momento do lógico, ou seja, da ideia da justiça, que preside à concepção da República - pressupõe a presença reguladora da ideia de homem, portador da justiça, a ser definida em perfeita analogia com a ideia da cidade.

Platão, na República, afasta-se ${ }^{45}$ do rígido dualismo órfico-pitagórico somapsyche exposto no Fédon. Adota ${ }^{46}$ o esquema tricotômico tritta eide psyches (três faculdades da alma): logistikon (racional), thymoeides (irascível) e epithymetikon (concupiscível) em analogia com a estrutura social do modelo da pólis. O agir de cada uma delas implica o movimento da alma toda, e a faculdade racional arbitra o conflito que daí resulta ${ }^{47}$. Suas virtudes, anteriormente descobertas na ordem da pólis ${ }^{48}$, são, respectivamente, sophia (sabedoria) do logistikon, andréia (coragem) do thymoeides, sophrosyne (temperança) do epithymetikon. Delas resulta a ordem na alma, regida pela dikaiosyne que a todas preside. A Antropologia da República, a partir da consideração que a psyché, depois da pólis, é o lugar procurado de morada da justiça, mostra sua originalidade frente ao precedente pensamento antropológico grego ao introduzir o conceito de justiça interior sob a forma da harmonia, concórdia e paz interiores do homem justo.

O cerne do encadeamento argumentativo da República vai do livro V 474d 1 até o fim do livro VII, onde Platão faz longa exposição sobre a Filosofia, o Filósofo, as Ideias, a Dialética e a Paideia do Filósofo. A necessidade, inerente à lógica do discurso sobre a Justiça, de demonstrar a afirmação que somente ao Filósofo cabe governar a cidade, ordenada segundo o modelo Ideal oferece a ocasião para esta exposição. Aos olhos de Platão, essa afirmação, não obstante o paradoxo ${ }^{49}$ que possa representar, decorre da natureza e das possibilidades da realização da pólis assim ordenada. Com efeito, se só ao Filósofo pertence conhecer as Ideias e a Ideia suprema do Bem, e se a pólis justa não é senão a imitação da pólis ideal, toda iluminada pelo sol do Bem, como tentar implantar na realidade empírica essa imitação senão sob a guia daquele que conhece as Ideias e contempla o Bem? Cabe observar que a pólis e o Filósofo descritos por Platão permanecem em sua condição empírica, sujeitos às imperfeições dessa condição. A pólis ideal tem seu lugar no céu das Ideias ${ }^{50}$ e a ela se refere sua imitação terrena.

\footnotetext{
${ }^{45}$ Rep. IV 434d $2-441 \mathrm{c} 3$.

${ }^{46}$ Rep. VI, 504a 5-6; ver X, 595b 2.

${ }^{47}$ Rep. IV, 436a 8 - 440a 7.

${ }^{48}$ Rep. IV, 427e 9 - 428a 11; em Leis XII, 964b 6 Platão as enumera na seguinte ordem andréia, sophrosyne, dikaiosyne e phronesis.

49 Rep. V, 473e 4.

${ }^{50}$ Rep. X, 592b 3-7.
} 
Para que o Filósofo possa cumprir essa missão é necessário apresentá-lo não somente como amante da sabedoria, mas ainda como possuidor da ciência - a dialética - que lhe permitirá contemplar na ideia de homem e de Estado a norma ideal a ser realizada nos indivíduos e na comunidade. Essa formação do filósofo para a dialética ilumina a digressão feita a partir do livro VI, 502c e no livro VII. A impostação político-ética feita até então se alarga numa discussão epistemológico-metafísica que deve ser lida como resposta ao problema que se formulava em torno das categorias bíos politikós (vida política) e eudaimonía (felicidade ou excelência da vida) que coroa o eu práttein (bem agir). Nela se ilumina, em todas suas dimensões, o espaço conceptual dentro do qual os termos com que essas categorias se formulam - pólis, eudaimonía, physis, nómos - mostram o núcleo inteligível que permite articulá-los num lógos coerente. É esse lógos que se desdobrando nessa trilha temática deixa-se reconhecer em sua germinalidade como ideia de sistema em Platão.

A tese defendida por Trasímaco no livro I da República, e anteriormente por Cálicles no Górgias, expressa as relações que se estabelecem entre esses termos na vida política da pólis existente e que configuram a face da aporia com a qual se veem às voltas os interlocutores da República. A relação de poder geradora de injustiça vigora entre a pólis e a eudaimonía. A pseudoeudaimonía, nascida do poder e da riqueza na pólis injusta, apresenta-se como fruto do nómos que a physis impõe à vida política. Essa desordem da pólis empírica que reside na stásis (cisão) é a lei do mais forte, que separa os cidadãos desde que se submetam àquela que o nómos da physis impõe à vida política. Ela identifica eudaimonía com poder e riqueza e permite exaltar a pseudoeudaimonía do tirano como coroa da suprema injustiça do seu agir. A reordenação dessa relação de sorte a torná-la expressão do lógos verdadeiro pede a negação da desordem da lei do mais forte na pólis empírica.

A reordenação das relações entre os termos que se situam nos pontos cardeais do espaço da vida política redefine a unidade da pólis referindoa ao modelo ideal que o filósofo realiza primeiramente em si, para dedicarse à tarefa da sua realização concreta na comunidade, em meio às vicissitudes da história. A contemplação do modelo ideal só é possível a quem percorre o makrotéra períodos (mais longo circuito) ${ }^{51}$. O tema da digressão filosófica na República, justamente, descreve este circuito. É o caminho da dialética, em cujo termo a Ideia do Bem brilhará como objeto da mégisthon máthema (ciência mais alta) ${ }^{52}$.

\footnotetext{
${ }^{51}$ Rep. VI, 504b 3.

${ }^{52}$ Rep. VI, 505a 2-3.
} 
Os embaraços de Sócrates diante da insistência de Glauco ao pedir a definição do $B^{53}$ e, também, a referência à daimonías hyperbolés (transcendência estupenda) em que o Bem é colocado epékeina tes ousías (para além do Ser $)^{54}$ podem embasar a interpretação da dialética do Bem como ponto em que a órbita do pensamento platônico, na República, atinge sua maior distância da terra, a ela só retornando na descrição dos estágios da formação do dialético na segunda parte do livro VII e na tipologia dos Estados e dos seus governantes nos livros VIII e IX. Platão, no entanto, nunca esteve tão perto da realidade, ou mais concretamente, dos problemas da cultura ateniense, do que nessas páginas.

Platão usa a forma linguística da analogia ${ }^{55}$ entre a preeminência da Ideia do Bem no noetón (mundo inteligível) e a preeminência do Sol nas oratá (mundo das coisas visíveis) para falar do Bem. Graças a ela expõe a condição suficiente e necessária para que a vida política de Atenas possa ser reordenada segundo as exigências de um seguimento coerente do lógos, ou seja, segundo as exigências da submissão ao lógos verdadeiro. Só a visão sinótica ${ }^{56}$ própria do dialético, alcançada quando o Filósofo chega ao termo do seu makrotéra períodos, pode satisfazer essa condição. A partir deste alto cimo que é a contemplação do Bem, ele poderá voltar à cidade para reordená-la de acordo com a visão sinótica que se desdobra agora a partir da Ideia suprema do Bem-Uno.

A articulação da Theoría das ideias com a Protologia ou Doutrina dos princípios, enquanto apresenta a theoría da Filosofia, serve de exposição da Dialética nos livros centrais da República. A partir da digressão filosófica dos livros VI e VII, pode-se concluir que as desmesuras e as deficiências da práxis política dos Estados existentes não podem ser avaliadas e, portanto corrigidas, senão por uma medida perfeita, já que "nada de imperfeito pode ser medida do que quer que seja" ${ }^{\prime 57}$. Essa medida perfeita somente é encontrada no conhecimento do supremo inteligível, ou seja, a Ideia do $\mathrm{Bem}^{58}$. O distanciamento inicial da theoría relativamente à práxis é rigorosamente medido nos seus estágios. A comparação da linha ${ }^{59}$ descreve sua estrutura epistemológica. A alegoria da caverna ${ }^{60}$ traça seu caminho pedagógico. O filósofo, instruído pela theoría, ou seja, cumpridos esses estágios e contemplado o Bem, pode então retornar ao mundo da práxis.

\footnotetext{
${ }^{53}$ Rep. VI, 506b $3-\mathrm{e} 2$.

${ }^{54}$ Rep. VI, 509b 6 - c 2.

${ }^{55}$ Rep. VI, 506d $3-509 \mathrm{~b} 10$.

${ }^{56}$ Rep. VII, 537c 7.

${ }_{57}$ Rep. VI, 504c 3.

${ }^{58}$ Rep. VI, 504d 4-5.

${ }^{59}$ Rep. VI, 509d 7 - 511c 11.

${ }^{60}$ Rep. VII, 514a 1 - 516b 11.
} 


\section{A propósito das trilhas percorridas}

A ideia germinal de sistema em Platão vai se mostrando, nos contornos das duas trilhas temáticas percorridas, imbricada com a significação desse vasto mosaico em que se interrelacionam a Vida filosófica e suas condições, a Filosofia e a suprema altitude inteligível de seu objeto, e a Ética, Ciência do éthos, como Ciência do Bem. Seu desenho fundamental mostrase ao se alcançar o ápice da ascensão dialética ${ }^{61}$ até a Ideia do Princípio Primeiro da inteligibilidade e do $\operatorname{ser}^{62}$ contemplada segundo a conceptualidade do Bem absoluto.

Platão, obedecendo à lógica da refutação e superação do relativismo dos sofistas, um dos alvos constantes do seu pensamento, é levado a afrontar o problema do fundamento absoluto do bem humano ${ }^{63}$, ou seja, a propor uma Metafísica do Bem. Nesse sentido, a escritura platônica da ideia de sistema torna a referência às categorias metafísicas constitutiva do pensamento ético. Essa é a óptica primeira das passagens em que Platão discorre sobre a Ideia do Bem em sua transcendência como objeto mais alto da Filosofia, em sua imagem - o Sol visível - e em seus efeitos como fonte do ser e de inteligibilidade ${ }^{64}$, bem como discorre sobre a contemplação da Ideia do Bem como termo do itinerário da dialética e da paideia do Filósofo ${ }^{65}$.

O problema da conciliação entre a necessidade do bem que emerge do discurso da razão e a liberdade do agir dentro de uma Filosofia da ordem encontra sua resposta somente no nível da contemplação da Ideia do Bem. A ideia de sistema em sua abertura metafísica começa a receber sua justificação justamente no nível em que a Ideia do Bem - termo último e absoluto da ascensão dialética, ou seja, do itinerário do lógos, e fim último e absoluto do caminho da liberdade (= práxis) - mostra-se como fonte de toda inteligibilidade e bondade e, por conseguinte, razão mesma da liberdade em sua verdade como atributo intrínseco do ser racional.

O pensamento grego carrega consigo a experiência da liberdade como confronto com o destino e como liberdade política na pólis. Distingue três formas de liberdade. Liberdade de arbítrio ou o poder de agir ou não agir ou de agir segundo o simples arbítrio de cada um. Liberdade de escolha, que é precedida ou acompanhada de deliberação da razão. Liberdade de autonomia que consiste na perfeita identificação da liberdade com o Bem da qual resulta a autárkeia, ou perfeito domínio de si mesmo. A liberdade de arbítrio acompanha os diálogos platônicos como franja inferior da liber-

\footnotetext{
${ }^{61}$ Rep. VII, 533c $9-534$ a 9.

${ }^{62}$ Rep. VI, 508e $1-509 \mathrm{~b} 10$.

${ }^{63}$ Rep. VI, 504d 5 - e 3.

${ }^{64}$ Rep. VI, 505a $1-509$ b 10.

${ }^{65}$ Rep. VII, 534b $3-\mathrm{d} 2$.
} 
dade, que não se eleva ao plano dos valores éticos. O verdadeiro caminho da liberdade tem início com a liberdade de escolha. A argumentação da República, construída em vista da fundamentação das virtudes, passa necessariamente além da deliberação em torno dos objetos empíricos e contingentes ou mesmo finitos e limitados para orientar-se para a Ideia do Bem, absoluto e supraessencial ${ }^{66}$ de cujo conhecimento deriva para todo caminho da liberdade a justificação racional de cada um de seus passos.

A alegoria da caverna, no início do Livro VII, tem declaradamente uma intenção pedagógica. Também pode ser interpretada como uma parábola do caminho da liberdade. Os prisioneiros no fundo da caverna, discutindo sobre as sombras que veem passar diante de si, vivem a ficção do livrearbítrio, oscilando daqui e dali entre objetos irreais. $\mathrm{O}$ prisioneiro libertado avança através de objetos reais, pelo exercício da liberdade de escolha orientada pelo mais real, isto é, pelo melhor. Finalmente, a liberdade atinge o ápice de seu itinerário quando o prisioneiro libertado pode contemplar o Sol, imagem do Bem em si, real realíssimo. É então, plenamente, liberdade de plena autonomia do sujeito livre em que o destino perde seu poder tirânico sobre o indivíduo efêmero, e a autárkeia do cidadão na pólis é elevada a um plano transcendente no qual deixa de ser condicionada pelas vicissitudes históricas da cidade.

As linhas fundamentais da ideia platônica de sistema convergem para a República, onde a ascensão dialética alcança seu ápice e seu desenho germinal se completa. Esse ápice é contemplado segundo a conceptualidade do Bem absoluto, ou seja, segundo a Ideia do Princípio primeiro da inteligibilidade e do ser. O télos do sistema é a redução ordenada do múltiplo ao Uno ou a introdução da ordem que procede do Uno na desordem do múltiplo. Esse movimento se cumpre seguindo o esquema vertical da ascensão e da descida, e o Uno preside à ordem do múltiplo sob a forma do bem organizando-o como universo.

Endereço do Autor:

Av. Unisinos, 950

Caixa Postal 275

93022-000 São Leopoldo - RS

e-mail: aquino@unisinos.br

${ }^{66}$ Rep. VI, 509b 10 - c 2. 